different tissues - may prove to be changes affecting what we might loosely call the ras and myc functions. Which of these steps usually occurs first will depend on which, if either, confers some survival advantage to cells within a tissue.

The evidence so far is that activation of cellular ras proto-oncogenes in naturally occurring cancers can be achieved by altering a single amino acid - which can result from changing a single base pair - and that $m y c$ activation involves a DNA rearrangement event. This could mean that at least one mutational event and one transposition or rearrangement event must occur in the natural history of many cancers. We have so far no direct evidence showing how to relate these events to phenomena such as initiation and promotion; nor can we say whether these steps are among those driven by environmental factors. But the way is open to determine whether mutagens in our food, for example, drive accumulation of the kind of mutations needed to activate ras genes; or whether oxidizing agents and protease in-

hibitors influence the chromosome rearrangements implicated so far in overexpression of the myc gene (in these experiments, and in the creation of certain human lymphomas).

It is not clear how many of the controls of cell behaviour have to be altered in order to create the commonest forms of cancer. Since most epithelial cells probably have a more complex programme of cell renewal than fibroblasts, and most epithelial cancers increase in frequency with age more steeply than sarcomas, more than two or three steps may be involved in the progression of a normal epithelial cell to a cancer. Eventually, transfection experiments will be done using epithelial cells, and we shall then see whether the additional steps involve still other members of the family of oncogenes that were originally revealed by the retroviruses.

John Cairns and Jonothan Logan are in the Department of Cancer Biology, Harvard School of Public Health, Boston, Massachusetts 02115.

\title{
Geology
}

\section{Swedish chronology revisited}

\section{from D.J. Schove and R.W. Fairbridge}

IN the 1940s the Swedish Time Scale based on a varve count over 14,000 years was the standard chronology for all parts of the world. From 1950 to 1980 its place was taken by radiocarbon. However, solar fluctuations ${ }^{1}$ and associated Holocene wiggles $^{2}$ soon emphasized the need for a distinction between ${ }^{14} \mathrm{C}$ dates (b.p./b.c.) and tree-ring dates $(\mathrm{BP} / \mathrm{BC})$. The Bristlecone pine chronology ${ }^{3}$ has enabled us to calculate the differences back almost to 9,000 yr BP or $7,000 \mathrm{BC}$, but before that we still need a scale reliably based on annual counts of varve layers. Some participants at a recent conference* suggested that in Sweden a reliable revision of the Swedish Time Scale will soon provide us with an accurate chronology of some 14,000 years.

There are several difficulties with the old Swedish Time Scale. First, the latest historical varves to be counted ${ }^{4}$ were given an estimated medieval date now known to be too late. Second, about 10,000 Holocene varves were counted by Liden from the Late Glacial (Zone III/IV which was thus dated at about $8,000 \mathrm{f} . \mathrm{Kr}$. in Sweden and which is indeed around 10,000 on the ${ }^{14} \mathrm{C}$ scale). However, such varves lack the thick meltwater component provided by glaciers and varves are easily missed. Liden's measurements were neither published ${ }^{4}$ nor replicated. If a thousand years ${ }^{5,6}$ were missed, $\sim 8,000$ f. $\mathrm{Kr} .=9,000 \mathrm{BC}=11,000 \mathrm{yr} \mathrm{BP}=10,000$ b.p.

"'Climatic change and related problems' was the theme of the Second Nordic Symposium held at Siockholm in May. The proceedings will be published in 1984 .
Third, the Late Glacial varves measured by De Geer ${ }^{7}$ are not as continuous as was thought. In more continental climates such as Finland and Canada, varves are more easily counted. Cross-dating of the Swedish and the Finnish scale in 1969 led to a suspicion ${ }^{8,9}$ that there was a discrepancy of nearly a century in the region of the Central Swedish moraines. It was pointed out ${ }^{9}$ that De Geer had bridged northern and southern series by using varve series from outside Europe altogether. The search for a better 'bridge' has failed (none may be needed, D.J.S.), but other errors ${ }^{4}$ have meanwhile been noticed by Lundqvist ${ }^{5,6}$ and N-A. Morner (University of Stockholm).

These difficulties are now being resolved. First, historical varves can now be obtained that continue to the present. A new coring method involving freezing in situ makes it possible to collect and measure even last year's varve: I. Cato (University of Uppsala) has thus measured and replicated series back to the medieval period. Historical series can be cross-dated with meteorological data (for example, Baltic ice data available back to 1720 discussed by L. Makkonen, University of Helsinki) to ensure that no varves have been missed.

Second, Holocene series can be crossdated with proxy meteorological data. Back to AD 436 we thus have a summer temperature index based on Lapland treerings by $T$. Bartholin and W. Karlen ${ }^{10}$ (University of Stockholm). New varve series, with an estimated error of only 1 per cent in the count, have already been analysed back 5,000 years and a chart of the data, exhibited by I. Renberg and U. Segerstrom (University of Umea), aroused great interest. Varve thickness, organic content, mineral matter content and visual appearance provide separate parameters that can be interpreted meteorologically.

Teleconnection with the Bristlecone pine absolute scale, using, for example, the quasi-biennial oscillation, has already been achieved for Bronze Age varves in south Russia and for tree-rings in Turkey" Similar methods will make it possible to correct whatever error exists in the dating.

Finally, glacial varves from the early Holocene have also been measured and the measurement replicated carefully ${ }^{12}$ using a new zero at Doeviken in northern Sweden. This Swedish zero can be equated ${ }^{13,14}$ with varve 1166 or 1167 in the reliable Canadian (Timiskaming) varve series. Cross-dating the subsequent Canadian varves with further Swedish lake varves being investigated by Renberg will make exact dating possible through the early Boreal period (Zone V).

In the south of Sweden where new floating chronologies are being obtained, thick annual (proximal) varves can be subdivided into diurnal varves recording the number of days in the pre-Bolling summers. Such a series should correlate with the floating chronology of the varves in southern New England.

In central Sweden the failure to find a bridge is no longer a problem if the Finnish chronology $9,13,14$ is accepted: none is needed. Other studies, including palaeomagnetism, dating of shorelines and oxygen-18, are being carried out by Morner and others. Many papers provided precise radiocarbon chronologies for other parts of the world, including the Tropics and Canada. For instance, logs from Siberia were transported north of Lapland to dated Spitzbergen shorelines not in warm periods as previously thought but in cold periods; as A. Häggblom (University of Stockholm) discovered they were transported not by water but by ice.

D. J. Schove is at St Davids College, West Wickham, Kent BR4 OOS and R. W. Fairbridge is in the Department of Geological Sciences, Columbia University, New York 10027.

1. Schove, D.J. Sunspot Cycles, 337 (Hutchinson Ross, Stroudsburg, 1983)

2. Fairbridge, R.W. Nature 292, 670 (1981)

3. Farguson, C.W. \& H.E. Suess in Radiocarbon Variations and Absolute Chronology (ed. Olsson, 1.U.) 237 (Wiley, London, 1970).

4. Fromm, E. in Radiocarbon Variations and Absolute Chronology (ed. Olsson, 1.U.) 163 (Wiley, London, 1970).

5. Schove, D.J. Sunspot Cycles, 337, 361 (Hutchinson Ross, Stroudsberg, 1983)

6. Lundqvis1, J. Boreas 4,47 (1975)

7. De Geer, G. Geochronologia Suecica Principles (Stock. holm, 1940).

8. Schove, D.J. Geogr. J. 135, 598 (1969).

9. Schove, D. J. Geogr. Annal. 53, 227 (1971).

10. Bartholin, T.S. \& Karlen, W. Dendrokronologi i Lapland, Dendrokronologiska Sallskapet, Stockholm 5, 1 (in Swedish).

11. Schove, D.J. Sunspot Cycles, 351 (Hutchinson Ross, Stroudsberg, 1983)

12. Bergstrom, R. Sver. Geol. Unders. C634, 77 (1968).

13. Schove, D.J. Geogr. Annal 53, 230 (1971).

14. Schove, D.J. \& Fairbridge, R.W. Ice-cores, Varves and Tree-Rings (Balkema, Rotterdam, 1984). 